\title{
SEASONAL DYNAMICS IN CARBON DIOXIDE FLUXES OF THE HERBACEOUS LAYER OF A MOIST KENYAN SAVANNAH
}

\author{
GEORGE O. K'OTUTO* ${ }^{\prime 1}$ - DENNIS O. OTIENO ${ }^{2}$ - JOHN C. ONYANGO ${ }^{3}$ - HARUN O. OGINDO ${ }^{1}$ \\ ${ }^{1}$ Applied Plant Science Department; Maseno University \\ Private Bag 40105 Maseno, Kenya; \\ (phone: +254-57-351622; fax:+254-57-351221; email: ogindo_harun@yahoo.com, \\ georgekotuto@yahoo.com) \\ ${ }^{2}$ Plant Ecology Department, University of Bayreuth \\ 95440 Bayreuth, Germany \\ (email:dennis.otieno@uni-bayreuth.de) \\ ${ }^{3}$ Botany Department; Maseno University, \\ Private Bag 40105 Maseno, Kenya; \\ (phone: +254-57-351622; fax.+254-57-351221; email: jconyango@yahoo.com) \\ *Corresponding author \\ e-mail: georgekotuto@yahoo.com \\ (Received 22 $2^{\text {nd }}$ May 2012 ; accepted $22^{\text {nd }}$ July 2014)
}

\begin{abstract}
Strong seasonal variability in African carbon source/sink relationship is considered the continent's most significant contribution to the global carbon cycle. Alternating dry and wet periods dictate ecosystem carbon exchange and productivity of tropical African savannah. We examined the seasonal and daily trends in ecosystem $\mathrm{CO}_{2}$ exchange in the herbaceous layer of a humid Kenyan savannah devoid of grazing. Microclimate, soil moisture, soil and tissue nitrogen, aboveground biomass and carbon dioxide fluxes were measured. The ecosystem carbon dioxide fluxes followed the seasonal rainfall pattern and were strongly correlated to soil water content. Peak mean carbon dioxide fluxes were $3.21 \pm 0.99,8.21 \pm 1.02$ and $4.67 \pm 1.06 \mu \mathrm{molm}^{-2} \mathrm{~s}^{-1}$ during drought and $-13.86 \pm 1.48,15.03 \pm 0.98$, and $27.73 \pm 1.47 \mu \mathrm{molm}^{-2} \mathrm{~s}^{-1}$ during wet periods for net ecosystem carbon dioxide exchange, ecosystem respiration and gross primary production respectively. At daily scale, net ecosystem carbon dioxide exchange increased with increasing photosynthetic photon flux density under wet but decreased with increasing vapour pressure deficit under dry conditions. Ecosystem respiration increased with increasing soil temperature during wet but decreased with increasing soil temperature during drought. Our results point to the overriding role of soil moisture in the ecosystem carbon dioxide exchange processes of this savannah.
\end{abstract}

Keywords: African savannah, CO2 chambers, ecosystem respiration, net ecosystem exchange, soil moisture

\section{Introduction}

Increasing atmospheric concentration of $\mathrm{CO}_{2}$ is the largest contributor to global climate warming and associated extreme weather events (IPCC, 2007). This makes the global carbon cycle highly important to the "stabilization of greenhouse gas concentrations in the atmosphere at a level that would prevent dangerous anthropogenic interference with the climate system" the sole objective of the United Nations Framework on Climate Change (UNFCC). In the global carbon (C) cycle, atmospheric $\mathrm{CO}_{2}$ is mainly taken up by the terrestrial biosphere via plant photosynthesis or gross primary production (GPP). This photosynthetic phenomenon underscores the important role played by plants in regulating atmospheric $\mathrm{C}$ concentrations. In Africa, the 
savannah ecosystem that covers about two-thirds of the continent's land surface (Adams, 1996) must be a major player in the regional and global $\mathrm{C}$ balances (Grace et al., 2006).

Ecosystem carbon exchange in African savannah though previously poorly studied is currently receiving substantial attention (Williams et al., 2007; Ardö et al., 2008; Bombelli et al., 2009; Ciais et al., 2009; Otieno et al., 2010; 2011). However, despite the renewed interest in the carbon budget of African savannah in the second half of the last decade, the continent's savannah is extensive and both spatially and temporally variable (Ciais et al., 2009; Williams et al., 2007). Such great variability in the continent's largest ecosystem is greatly impacting its carbon balance since exchanges of $\mathrm{CO}_{2}$ between land surface and atmosphere in savannah are highly modulated by ecosystem characteristics such as structure, species and physiological functions (Beringer et al., 2011). The variability of the African carbon balance has been noted and is estimated to account for about $50 \%$ of inter-annual variability in global atmospheric $\mathrm{CO}_{2}$ (Williams et al., 2007). The high variability coupled to complex interactions between biotic and abiotic factors that control plant productivity may be responsible for the continent's large contribution to the uncertainty in its $\mathrm{C}$ budget and needs to be understood. Clear understanding of the temporal variability in African savannah is needed for better parameterization of the models estimating the continent's carbon exchanges and consequently unraveling the uncertainties in its $\mathrm{C}$ balance.

Savannahs are characterised by two different plant functional types, namely the grass herbaceous layer and the tree/shrub over-storey in regions with alternating wet and dry seasons (Grace et al., 2006; Scholes \& Archer, 1997). The dry and wet seasons are associated with strong seasonal changes in soil moisture and temperature regimes (Kanniah et al., 2010; Scholes \& Archer, 1997) that influence nutrient availability, vegetation growth, fire occurrence and decomposition (Scholes, 1990; Scholes \& Walker 1993; Rodriguez-Iturbe et al. 1999; Ciais et al., 2011). The different plant functional forms in savannah may however, not respond in a similar way to this climatic seasonality further creating a source of ecosystem variability. In particular the shallow rooted herbaceous vegetation has their productivity synchronised to the wet season when soil water content is high but senesce during drought (Scholes \& Walker, 1993; Xu \& Baldocchi, 2004). This makes the herbaceous layer a more variable component of the savannah ecosystem and thus a better candidate for variability study.

Closely tied and driving these seasonal climatic variations in the African savannah, are daily variations in weather patterns. African savannah experiences daily variations in solar radiation and water vapour pressure leading to variations in temperature, photosynthetic photon flux density (PPFD), and vapour pressure deficit (VPD). Such daily changes in weather patterns result in daily variation in ecosystem $\mathrm{CO}_{2}$ fluxes (Maherali et al., 2003; Flanagan \& Johnson 2005; Hastings et al., 2005; Risch \& Frank, 2010). In particular, PPFD (Dai et al., 2004; Hastings et al., 2005) and VPD (Maherali et al., 2003) determine ecosystem photosynthesis whereas environmental temperature (Joffre et al., 2003; Flanagan \& Johnson, 2005; Li et al., 2008) largely influences ecosystem respiration.

Despite the strong link between daily weather and seasonal variations in microclimatic factors and their great influence on ecosystem $\mathrm{CO}_{2}$ fluxes in African savannah, the seasonality of $\mathrm{CO}_{2}$ fluxes in the continent's savannah is poorly studied (Ardö et al., 2008). Concurrent analysis of daily, intra annual and inter-annual carbon exchange trends enhances the understanding of the physical and physiological controls 
of carbon fluxes and functioning of ecosystems. In-depth understanding of the factors regulating ecosystem $\mathrm{C}$ dynamics of African savannah will further help refine and validate the models currently used to estimate the continent's $\mathrm{C}$ balance and to inform policies related to the role of Africa in regional and global carbon cycle.

The two known methods for direct measurements of ecosystem $\mathrm{CO}_{2}$ exchange are the eddy covariance (EC) and the chamber techniques (Hall et al. 1992; Wohlfahrt et al. 2005) both of which have been compared in detail by Wohlfahrt et al. (2005). The greatest effort to assess the African carbon budget has been that of the CarboAfrica project (http://www.carboafrica.net), using the EC method (Ardö et al. 2008; Merbold et al. 2008). The chamber method whose results compare favourably with eddy data, when both are used in parallel (Li et al. 2008) is useful in heterogeneous landscapes and when the focus is to separate fluxes from the different ecosystem patches. The chamber method has widely been used for $\mathrm{CO}_{2}$ measurements in the temperate (Li et al. 2008), Peatlands (Otieno et al. 2009) and in the African savannah (Otieno et al. 2010; 2011) ecosystems. We used the chamber method to measure the ecosystem $\mathrm{CO}_{2}$ exchanges in the herbaceous layer of a moist African savannah.

In this study, we examined how climatic seasonality affects biomass development and ecosystem $\mathrm{CO}_{2}$ exchange of a moist savannah. How do the ecosystem $\mathrm{CO}_{2}$ fluxes change with season at both daily and seasonal scale? What drives the daily and seasonal $\mathrm{CO}_{2}$ fluxes in a moist savannah? The study singles out the herbaceous layer (the most seasonal component) of the moist savannah. Given the distinct droughts and wet periods of African savannahs (Otieno et al., 2010; 2011; Scholes \& Archer, 1997; Kutsch et al., 2008), we divided the year into three periods of different phases of soil moisture (wet, intermediate and dry) as dictated by rainfall distribution.

\section{Materials and Methods}

\section{Study Site}

The study was conducted at the Kenya National Youth Services (NYS) station $\left(00^{0} 36^{\prime} 28^{\prime \prime} \mathrm{S} \& 34^{0} 15^{\prime} 24^{\prime \prime} \mathrm{E}\right)$ in Lambwe valley, Nyanza province of Kenya during the year 2009. The NYS station borders Ruma National Park. The altitude of the valley ranges between 1200 and $1400 \mathrm{~m}$ above sea level. The terrain is mainly rolling grassland with tracts of open woodland and thickets dominated by Acacia ancistroclada, A. gerarrdii, Rhus natalensis, R. vulgaris, Pilliostigma thonningii and Belanites aegyptica trees. The dominant grass species was Themeda triandra while the soils are vertisols according World Reclamation Bureau (WRB). The climate is hot and humid with a mean air temperature of $22.5^{\circ} \mathrm{C}$. Mean annual rainfall for the last 15 years is $1346 \mathrm{~mm}$ with a bimodal distribution pattern between April-June and SeptemberNovember. The months of January and February are the driest and hottest.

The NYS station has about 40 ha land in which they rear livestock and grow crops. The studies were conducted in a $70 \mathrm{~m} \times 100 \mathrm{~m}$ area that was previously grazed, but had a $2 \mathrm{~m}$ high fence erected to exclude the grazing livestock for three years prior to the commencement of the study.

\section{Experimental Design}

The study aimed at determining the seasonal variations in ecosystem $\mathrm{CO}_{2}$ exchange and productivity of the herbaceous layer of a moist savannah. The year was divided into 
three periods namely wet (April-June and September-November), intermediate (JulyAugust) and dry (January-March) with different phases of soil moisture. The transitions from short rains (September-November) to the dry period at the study site are rather abrupt making December to either be a wet or dry month depending on when the rains cease. The periods/months were the treatments. The $70 \mathrm{~m} \times 100 \mathrm{~m}$ fenced block was divided into approximately three equal parts from east to west resulting into strips $(30 \mathrm{~m}$ x $70 \mathrm{~m}$ ) running north-south down-slope. Each of the three strips represented the replicates and was randomly sampled for measurements taking care to avoid areas under the tree canopies and close to termitaria which had been found to influence $\mathrm{CO}_{2}$ exchange (Otieno et al., 2011). The collars/frames measuring $39.5 \mathrm{~cm}$ by $39.5 \mathrm{~cm}$ used in carbon flux measurements were used as quadrats for biomass harvesting. Measurements were conducted every month.

\section{Measurements}

\section{Micrometeorology}

A microclimate station was set up in an open area of the study site at a height of 2 m. Rainfall (RG3 HOBO pedant rain gauge, HOBOware, Eichstetten, Germany), air temperature and humidity (FUNKY-Clima, ESYS, Berlin, Germany), and global radiation (HOBO pedant, HOBOware, Eichstetten, Germany) were the weather parameters measured. Measurements were taken every 30 seconds and averaged and stored every 30 minutes into in-built data loggers. In addition soil temperature at $10 \mathrm{~cm}$ depth was measured within the chambers (see net ecosystem $\mathrm{CO}_{2}$ exchange below) using digital thermometers (Einstichthermometer, Conrad, Hirschau, Germany) during carbon dioxide flux measurements. Vapour pressure deficit (VPD) was computed from ambient air temperature and relative humidity. Saturation vapour pressure $\left(\mathrm{VP}_{\text {sat }}\right)$ was first computed from the Arrhenius equation. Actual partial pressure of water vapour $\left(\mathrm{VP}_{\text {air }}\right)$ was then computed from saturation vapour pressure and relative humidity:

$$
\text { VPair }=\text { VPsat } * R H / 100
$$

Vapour pressure deficit (VPD) was then computed as the difference between $\mathrm{VP}_{\text {sat }}$ and $\mathrm{VP}_{\text {air. }}$

\section{Soil water content}

Soil samples for gravimetric soil water content (SWC) were obtained every month from $0-10 \mathrm{~cm}, 10-20 \mathrm{~cm}$ and $20-30 \mathrm{~cm}$ depths using a soil augur. The soils were weighed immediately after sampling, oven dried at $105^{\circ} \mathrm{C}$ to constant weight and then re-weighed to determine its water content. Gravimetric soil water content was determined as the relative change in weight between fresh and dry soil samples.

\section{Soil and plant carbon and nitrogen determination}

Carbon (C) and nitrogen $(\mathrm{N})$ concentration in the soil, root and shoot were determined. Soil and shoot samples were obtained from part of soil moisture and shoot biomass samples respectively. Root samples were obtained monthly using a root augur. 
Samples (shoots, roots, and soil) were then dried and homogenised in a ball mill. The homogenised samples were re-dried in a desiccator to eliminate all water. Approximately $5 \mathrm{~g}$ of the dried soil and $1 \mathrm{~g}$ of plant samples were then analysed to determine their $\mathrm{C}$ and $\mathrm{N}$ concentrations (\%) using elemental analysis according to Markert (1996).

\section{Net ecosystem CO2 exchange (NEE)}

Net ecosystem $\mathrm{CO}_{2}$ exchange (NEE) was measured using a portable, temperaturecontrolled $40 \mathrm{~cm} \times 40 \mathrm{~cm} \times 54 \mathrm{~cm}$ transparent (三light) closed chamber system (Droesler, 2005; Otieno et al. 2010). The light chamber was constructed from a $3 \mathrm{~mm}$ thick Plexiglas XT type 20070, with $>95 \%$ light transmittance. To ensure closed-air circulation, plastic collars with base area of $39.5 \mathrm{~cm} \times 39.5 \mathrm{~cm}$ and $10 \mathrm{~cm}$ height, externally fitted with a $3 \mathrm{~cm}$ wide platform (3 cm from the top) were inserted approximately $5 \mathrm{~cm}$ into the soil at the beginning of the season. Chambers were sealed to the plastic frames/collars with a flexible rubber gasket and the chamber firmly secured using elastic straps fastened onto the ground from two sides. Extension bases were used to adjust chamber height to the canopy height. Tests were done to check that leakage did not occur, however, this could not be examined regularly in the case of systematic field measurements and each set of data was scrutinised for abnormalities.

The chamber temperature was maintained within $2^{0} \mathrm{C}$ of the ambient using frozen cool packs and air inside the chamber was mixed using three fans. Air temperature within and outside the chamber was continuously monitored and recorded during the flux measurements to check against wide variations. Sudden rise in pressure within the chamber was avoided by having a $12 \mathrm{~mm}$ diameter vent at the top of the chambers. This vent was opened during the placement of the chamber on the collars and replaced soon after the chamber was secured on the collars but before the onset of $\mathrm{CO}_{2}$ flux measurement.

Carbon dioxide concentration inside the chamber was measured using a portable infrared gas analyser (IRGA, LI-820, LI-COR, USA) connected to the chamber via flexible $0.32 \mathrm{~cm}$ diameter inflow and outflow tubes (Droesler, 2005). A battery-driven pump maintained a constant airflow rate through the IRGA-chamber system. Once a steady state was attained in the chamber system, $\mathrm{CO}_{2}$ concentration (ppm) was recorded every $15 \mathrm{~s}$ for a period of $2 \frac{1}{2}$ minutes before shifting to the next collar. Photosynthetic photon flux density (PPFD) above the grass canopy inside the chamber was measured using a PAR sensor (LI-190, LI-COR, USA) and logged alongside the $\mathrm{CO}_{2}$ concentrations. Soil temperature within the chambers at $10 \mathrm{~cm}$ depth was recorded, at the start and end of the $\mathrm{CO}_{2}$ concentration measurements, from digital thermometers (Einstichthermometer, Conrad, Hirschau, Germany).

Changes in $\mathrm{CO}_{2}$ concentration within the chamber headspace was calculated by linear regression from a linear portion of the plot of $\mathrm{CO}_{2}$ against time for the duration of the measurement. $\mathrm{CO}_{2}$ fluxes were calculated according to Risch \& Frank (2010).

$$
\mathrm{CO}_{2} f l u x=\frac{\partial C \mathrm{O}_{2}}{\partial t} \times \frac{P V}{A R T}
$$


where $\frac{\partial \mathrm{CO}_{2}}{\partial t}=$ rate of change in $\mathrm{CO}_{2}$ concentration with time; $\mathrm{V}=$ volume of headspace within the chamber; $\mathrm{P}=$ atmospheric pressure; $\mathrm{A}=$ ground area enclosed by chamber; $\mathrm{R}=$ gas constant; $\mathrm{T}=$ air temperature $(\mathrm{K})$.

A functional relationship between PPFD and NEE, also known as the 'light response curve' described by a rectangular hyperbola (Gilmanov et al., 2007) (Eq. 3) was employed to parameterize NEE response to light, using Sigma Plot 8.0.

$$
N E E=-\frac{\alpha \beta Q}{\alpha Q+\beta}+\gamma 0
$$

where $Q$ is PPFD ( $\mu \mathrm{mol} \mathrm{m} \mathrm{m}^{-2} \mathrm{~s}^{-1}$ ), NEE ( $\left.\mu \mathrm{mol} \mathrm{CO} \mathrm{Cm}^{-2} \mathrm{~s}^{-1}\right), \alpha$ is an approximation of the canopy light utilization efficiency ( $\mu \mathrm{mol} \mathrm{CO}_{2} / \mu \mathrm{mol}$ photon), $\beta$ is the maximum $\mathrm{CO} 2$ uptake rate of the canopy $\left(\mu \mathrm{mol} \mathrm{CO} \mathrm{CO}_{2} \mathrm{~m}^{-2} \mathrm{~s}^{-1}\right)$ and $\gamma 0$ is an estimate of the average ecosystem respiration (Reco, $\mu \mathrm{mol} \mathrm{CO}_{2} \mathrm{~m}^{-2} \mathrm{~s}^{-1}$ ) occurring during the observation period.

\section{Ecosystem respiration $\left(R_{\text {eco }}\right)$}

A similar chamber system to that used for NEE measurement, but translucent (dark) was used to measure ecosystem respiration $\left(\mathrm{R}_{\mathrm{eco}}\right)$. The dark chamber was made of opaque PVC and further covered with an opaque insulation and reflective layer of aluminium. The light and dark chamber measurements were conducted cyclically on hourly intervals from early in the morning $(08: 00 \mathrm{hr})$ to evening $(18: 00 \mathrm{hr})$, resulting in 8-10 measurement cycles per day.

\section{Gross primary production}

Gross Primary Production (GPP) was estimated from the general equation (Li et al. 2008):

$$
\mathrm{GPP}=\mathrm{R}_{\mathrm{eco}}-\mathrm{NEE}
$$

where $\mathrm{R}_{\mathrm{eco}}=$ ecosystem respiration $\left(\mu \mathrm{mol} \mathrm{CO} \mathrm{Cm}^{-2} \mathrm{~s}^{-1}\right)$ and $\mathrm{NEE}=$ net ecosystem $\mathrm{CO}_{2}$ exchange $\left(\mu \mathrm{mol} \mathrm{CO} \mathrm{CO}^{-2} \mathrm{~s}^{-1}\right)$.

\section{Aboveground Biomass determination}

During each $\mathrm{CO}_{2}$ fluxes measurements, the collars $(39.5 \mathrm{~cm} \times 39.5 \mathrm{~cm})$ were used as quadrants in sampling grass biomass that was then harvested. The harvested biomass was separated into standing/live biomass and dead/litter biomass. All aboveground shoots made up the live, while all shed-off litter made up the dead biomass. The separated live and dead biomasses were oven dried at $75^{\circ} \mathrm{C}$ for $48 \mathrm{hr}$ to determine their dry weights. 


\section{Statistical analysis}

Statistical analysis was performed using GenStat Discovery Edition 3 (VSN International Ltd: http://www.vsi.co.uk). Monthly and periodic means were compared using ANOVA, with month/period as the fixed effects at significance level of $\mathrm{P} \leq 0.05$. We applied multivariate linear mixed-effects model in order to correct for the repeated measures in the different plots while interaction between factors were obtained from Generalized Liner Model (GLM). We checked the normality of the model residuals visually by normal probability plots, and we assured the homogeneity of variances and goodness of fit of the models by plotting residuals versus fitted values. Post hoc test for pair-wise comparison of means was conducted with Tukey-LSD test $(\mathrm{P}<0.05)$ while correlation was tested using Pearson correlation test.

\section{Results}

\section{Daily weather patterns}

Both vapour pressure deficit (VPD) and photosynthetic photon flux density (PPFD) increased from early morning to daily maximum values before declining (Figs. 1a and b) irrespective of the soil moisture phase. However, while PPFD peaked at midday, VPD peaked later between 13:00 and 15:00 hrs. Soil temperature also increased from early morning (Fig. 1c) but did not peak unlike VPD and PPFD.

As expected vapour pressure deficit in the dry period was significantly higher than that of the wet and intermediate periods. Vapour pressure deficit of the wet and intermediate periods only differed significantly after midday. There was no definite seasonal trend on daily PPFD. The dry periods had significantly higher soil temperature than the wet which in turn was higher than that of the intermediate periods. Largest fluctuations in soil temperature $\left(6 \pm 1^{0} \mathrm{C}\right)$ during the day occurred during the dry periods.

\section{Seasonal microclimate and soil conditions}

The rainfall pattern was bimodal with two peaks March to July and August to December (Fig. 2a). The total annual rainfall for 2009 was $1000 \mathrm{~mm}$ which was lower than the 15 year average of $1346 \pm 54 \mathrm{~mm}$. Mean monthly air and soil temperatures were highest during the dry period (January-March) and lowest during the wet months (April-May) and intermediate (July) (Fig. 2b). The mean monthly air and soil temperatures were $24.5^{\circ} \mathrm{C}$ and $25.7^{\circ} \mathrm{C}$ respectively. Annual variations in temperature were small, while daily fluctuations were large.

Gravimetric soil water content (SWC) within the 0-30 $\mathrm{cm}$ soil profile followed the rainfall pattern, increasing during the wet and declining during the dry months (Fig. $2 c$ ). SWC was lowest in January-February averaging $\approx 20 \%$ and highest in April-May at $\approx$ $40 \%$.

Both total soil nitrogen $(\mathrm{N})$ and carbon (C) were lowest $(0.226 \pm 0.01 \%$ and $2.77 \pm 0.19 \%$ respectively) during the dry period (February-March) and increased with the rains to peak at the end of the rains $(0.235 \pm 0.01 \%$ and $3.39 \pm 0.19 \%$ respectively) in June and $(0.283 \pm 0.01 \%$ and $3.96 \pm 0.19 \%$ respectively) in November (Fig. 3a). Shoot $\mathrm{N}$ was lowest $(0.342 \pm 0.16 \%)$ during the dry period, peaked $(1.10 \pm 0.15 \%)$ at the onset of the rains in April and then declined with declining SWC to $0.55 \pm 0.15 \%$ in August before increasing again to another peak $(1.01 \pm 0.15 \%)$ in November during the short rains (Fig. 3b). Root $\mathrm{N}$ increased slightly with the onset of rains from $0.573 \pm 0.09 \%$ in 
March to $0.696 \pm 0.07 \%$ in April but thereafter declined to $0.445 \pm 0.07 \%$ in May while the shoot $\mathrm{N}$ remained high at $1.05 \pm 0.15 \%$.
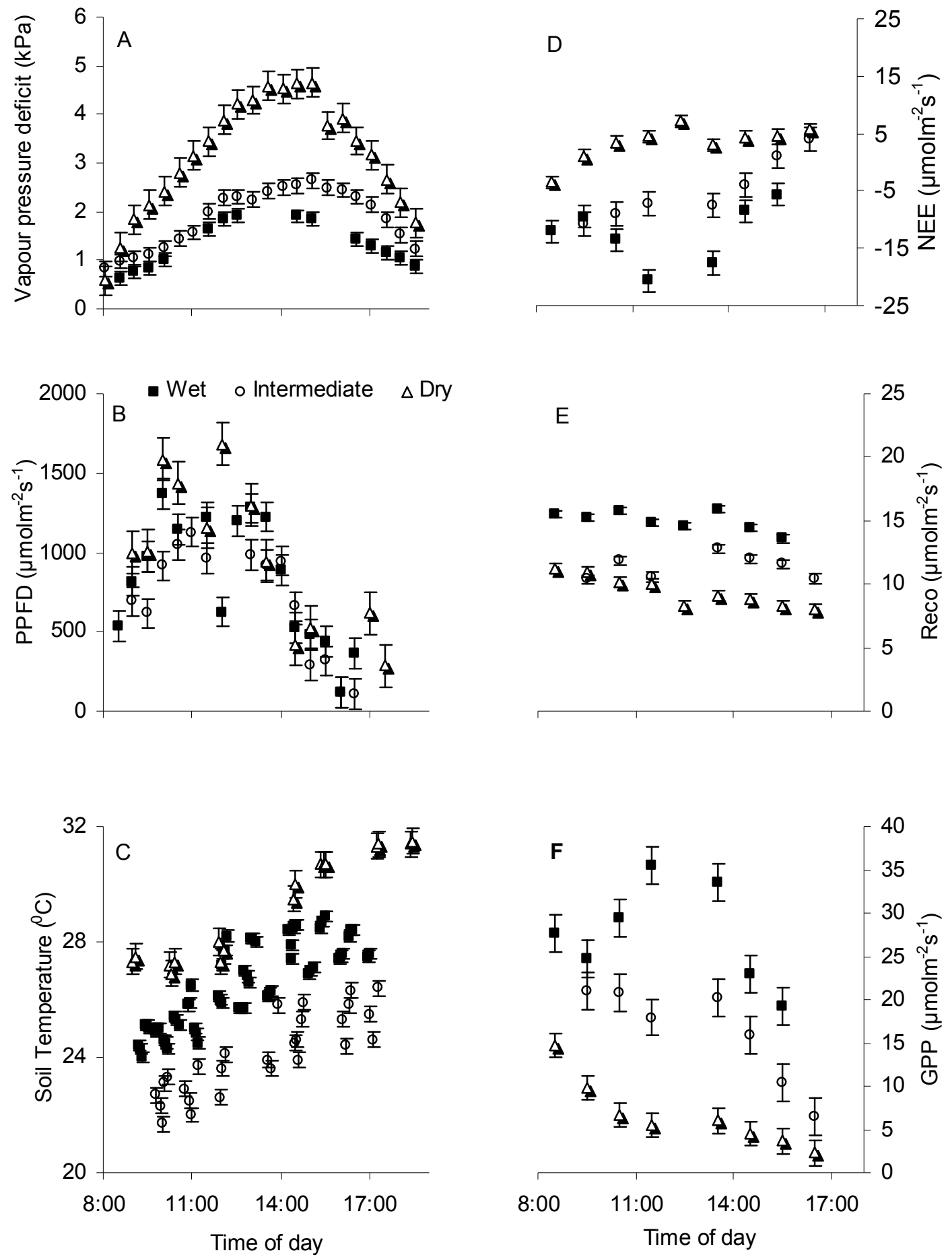

Figure 1: Daily trends of vapour pressure deficit (VPD) (a), photosynthetic photon flux density (PPFD) (b); soil temperature at $10 \mathrm{~cm}$ depth (c) net ecosystem CO2 exchange (NEE) (d); ecosystem respiration (e) and gross primary production (f) for dry, intermediate and wet, soil conditions. Values are means $( \pm S E)$ 

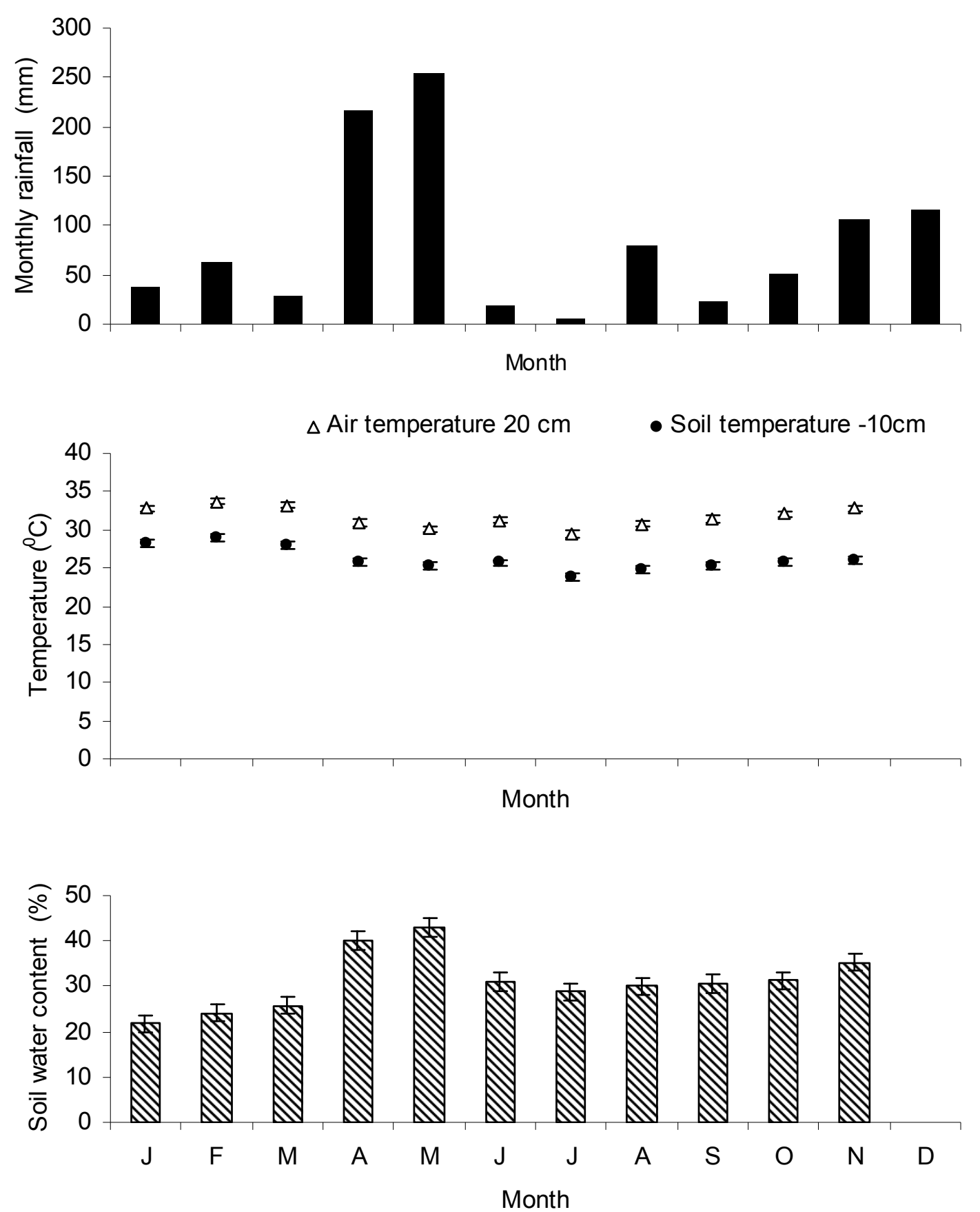

Figure 2. Monthly rainfall (a), mean soil and air temperature (b) and mean soil water content (SWC) during 2009.

As shoot $\mathrm{N}$ declined between May and August the root $\mathrm{N}$ levels increased by $50 \%$ from $0.445 \pm 0.07 \%$ to $0.880 \pm 0.07 \%$. The roots had higher $\mathrm{N}$ levels $(0.573 \pm 0.09 \%$ and $0.880 \pm 0.07 \%)$ compared to the shoots $(0.342 \pm 0.16 \%$ and $0.55 \pm 0.15 \%)$ during February - March and August respectively. Shoot carbon to nitrogen $(\mathrm{C}: \mathrm{N})$ ratio was low during wet months when conditions are conducive for growth and high during drought (Fig. $3 c)$. 

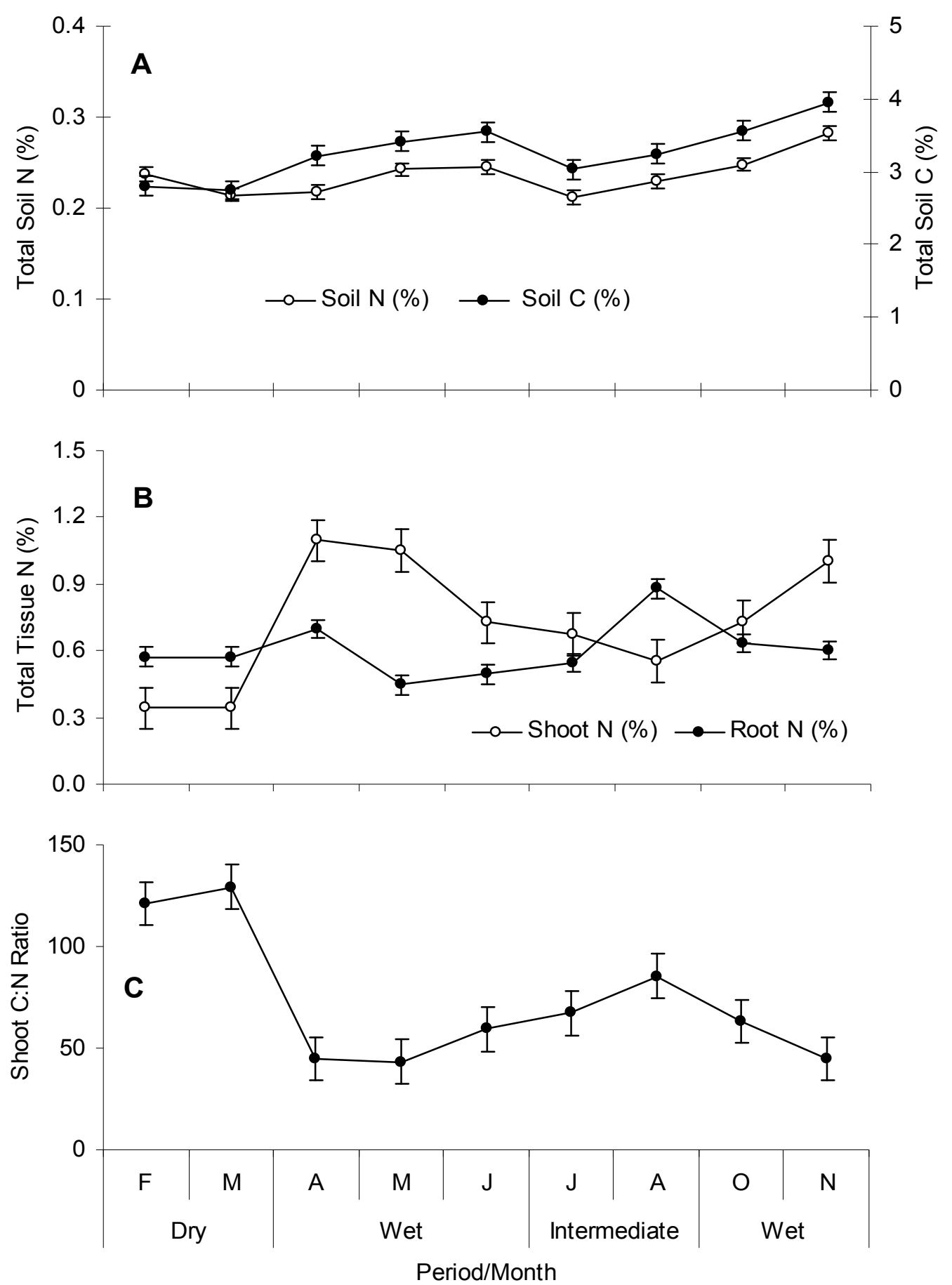

Figure 3. Total soil nitrogen $(N)$ and carbon $(C)(a)$, shoot and root $N(b)$ and shoot $C$ to $N$ ratio (c). Values are means $( \pm S E)$

\section{Aboveground biomass}

Both the total aboveground and dead/litter biomasses were highest (1426.1 \pm 71.3 and $553.4 \pm 31.1 \mathrm{gm}^{-2}$ respectively) during drought at the beginning of the year (February March) (Fig. 4a). Total aboveground and dead biomasses dropped to 529.5 \pm 64.3 and 
$154.0 \pm 28.5 \mathrm{gm}^{-2}$ respectively at the onset of the rains in April and then gradually increased to peak again at the end of the growing season in July-August (887.2 \pm 71.3 and $290.6 \pm 31.1 \mathrm{gm}^{-2}$ ).

\section{Carbon dioxide fluxes}

\section{Daily carbon fluxes}

Daily trends of GPP, NEE and $\mathrm{R}_{\text {eco }}$ differed with the soil water status (Figs. 1d, e, f). When water was readily available (wet), GPP and NEE increased from 27.65 and -12.10 $\mu$ molm ${ }^{-2} \mathrm{~s}^{-1}$ respectively in the morning to daily maximum values of 35.49 and -20.65 $\mu$ molm ${ }^{-2} \mathrm{~s}^{-1}$ respectively around midday before declining gradually to 19.24 and -5.66 $\mu$ molm ${ }^{-2} \mathrm{~s}^{-1}$ respectively by around 17:00 hrs (Figs. 1d, f). This trend was similar to that of PPFD but GPP and NEE peaked earlier than VPD by about 2 hrs. During the periods of dry and intermediate soil water condition, GPP was highest $(>10.00$ and $>20.00$ $\mu$ molm ${ }^{-2} \mathrm{~s}^{-1}$ respectively) in the morning (08:00 hr) and decreased as the day progressed to 2.28 and $6.46 \mu \mathrm{molm}^{-2} \mathrm{~s}^{-1}$ respectively after $16: 00 \mathrm{hrs}$. Net ecosystem $\mathrm{CO}_{2}$ exchange of the dry and intermediate periods followed a similar trend decreasing from $<-3.00$ and $<-10.00 \mu \mathrm{molm}^{-2} \mathrm{~s}^{-1}$ respectively in the morning to $>5.00$ and $>3.00 \mu \mathrm{molm}^{-2} \mathrm{~s}^{-1}$ respectively after 16:00 hrs. The dry period NEE values were always positive implying the ecosystem was a net $\mathrm{CO}_{2}$ source, while those of the wet period were always negative indicating a net $\mathrm{CO}_{2}$ sink, during these periods. The daily trends of NEE and GPP for the intermediate soil conditions were in between those of the dry and wet conditions.

Ecosystem respiration $\left(\mathrm{R}_{\mathrm{eco}}\right)$ varied little in the course of the day compared to GPP and NEE (Fig. 1e). It was almost unchanged in the morning $\left(15.56 \mu \mathrm{molm}^{-2} \mathrm{~s}^{-1}\right.$ at $08: 00$ and $15.86 \mu \mathrm{molm}^{-2} \mathrm{~s}^{-1}$ at $13: 30 \mathrm{hrs}$ ) before decreasing to $13.58 \mu \mathrm{molm}^{-2} \mathrm{~s}^{-1}$ after 16:00 during wet period. It increased from $10.37 \mu \mathrm{molm}^{-2} \mathrm{~s}^{-1}$ at $9: 00 \mathrm{hrs}^{-10} 12.78 \mu \mathrm{molm}^{-2} \mathrm{~s}^{-1}$ at 13:30 hrs before decreasing to $10.44 \mu^{2}$ molm $^{-2} \mathrm{~s}^{-1}$ after 16:00 $\mathrm{hrs}$ in the intermediate period. During the dry period, $\mathrm{R}_{\text {eco }}$ decreased from $11.19 \mu \mathrm{molm}^{-2} \mathrm{~s}^{-1}$ at $08: 00 \mathrm{hrs}$ to 8.02 $\mu$ molm $\mathrm{s}^{-1}$ by after 16:00 hrs.

\section{Seasonal carbon fluxes}

Net ecosystem $\mathrm{CO}_{2}$ exchange (NEE), ecosystem respiration $\left(\mathrm{R}_{\mathrm{eco}}\right)$, and gross primary production (GPP) followed the seasonal pattern of rainfall and SWC (Fig. 4b). Maximum net ecosystem $\mathrm{CO}_{2}$ exchange, $\mathrm{R}_{\text {eco max }}$ and $\mathrm{GPP}_{\max }$ were lowest at $3.21 \pm 0.99$, $8.21 \pm 1.02$ and $4.67 \pm 1.06 \mu \mathrm{molm}^{-2} \mathrm{~s}^{-1}$ respectively during drought (February-March) at the beginning of the year, increased (became more negative for $\mathrm{NEE}_{\max }$ ) with the onset of the rains to $-13.86 \pm 1.48,15.03 \pm 0.98$, and $27.73 \pm 1.47 \mu \mathrm{molm}^{-2} \mathrm{~s}^{-1}$ respectively in April, and gradually declined as the SWC decreased to reach the second low levels of $4.72 \pm 1.05,6.59 \pm 1.02$ and $9.16 \pm 1.62 \mu \mathrm{molm}^{-2} \mathrm{~s}^{-1}$ respectively in July. Maximum net ecosystem $\mathrm{CO}_{2}$ exchange, $\mathrm{R}_{\text {eco max }}$ and $\mathrm{GPP}_{\max }$ again increased thereafter from August as the rains resumed.

The seasonal fluctuations in $\mathrm{R}_{\text {eco max }}$ were relatively limited compared to those of the $\mathrm{NEE}_{\max }$ and $\mathrm{GPP}_{\max }$. Maximum net ecosystem $\mathrm{CO}_{2}$ exchange $\left(\mathrm{NEE}_{\max }\right), \mathrm{R}_{\mathrm{eco} \text { max }}$ and $\mathrm{GPP}_{\max }$ were positively correlated with SWC with $\mathrm{R}^{2}=0.79,0.63$ and 0.89 respectively (Fig. 4c). Maximum $\mathrm{R}_{\text {eco }}\left(\mathrm{R}_{\text {eco } \max }\right)$ was strongly correlated $\left(\mathrm{R}^{2}=0.68 ; \mathrm{P}<0.001\right)$ to, and a linear function of $\mathrm{GPP}_{\max }($ Fig. 4d). The three periods of different phases of soil moisture distinctly stood out in the GPP ${ }_{\max }$ vs. $\mathrm{R}_{\text {eco max }}$ correlation. 


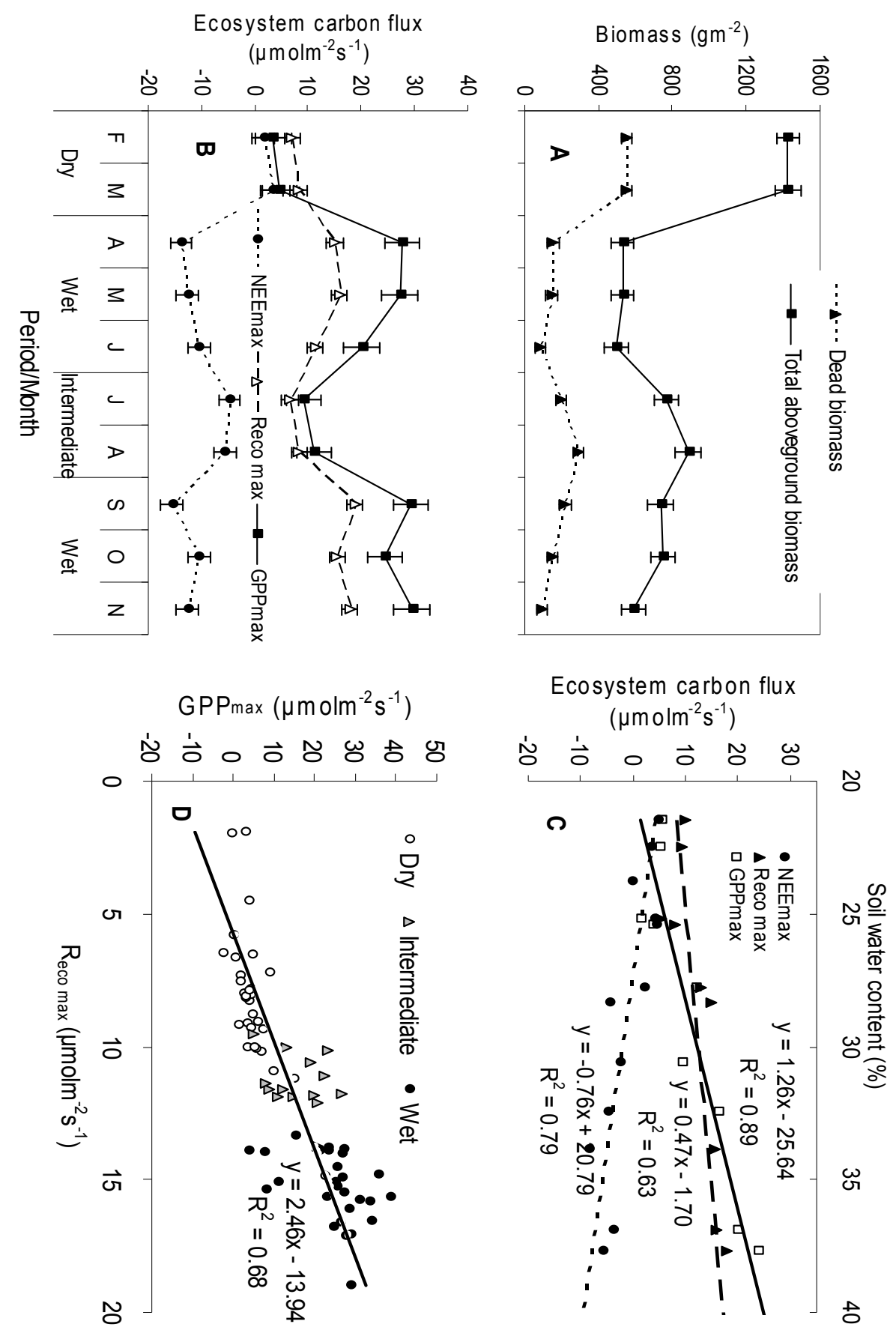

Figure 4. Total aboveground and dead biomass (a); Maximum net ecosystem CO2 exchange (NEEmax), ecosystem respiration (Reco max) and gross primary production (GPPmax) (b); and linear regressions, of SWC and NEEmax, Reco max, GPP max (c), and of GPPmax and Reco max $(d)$. Values are means $( \pm S E)$

Net ecosystem $\mathrm{CO}_{2}$ exchange was second-order polynomial non-linear function of VPD. It increased with increasing VPD when water was not limiting but decreased with increasing VPD under intermediate and dry soil conditions (Fig. 5a). The NEE Vs VPD correlations were moderate $\left(\mathrm{R}^{2}=0.50\right)$ under readily available soil water but strong under intermediate and dry conditions $\left(\mathrm{R}^{2}=0.84,0.92\right.$ respectively $)$. 


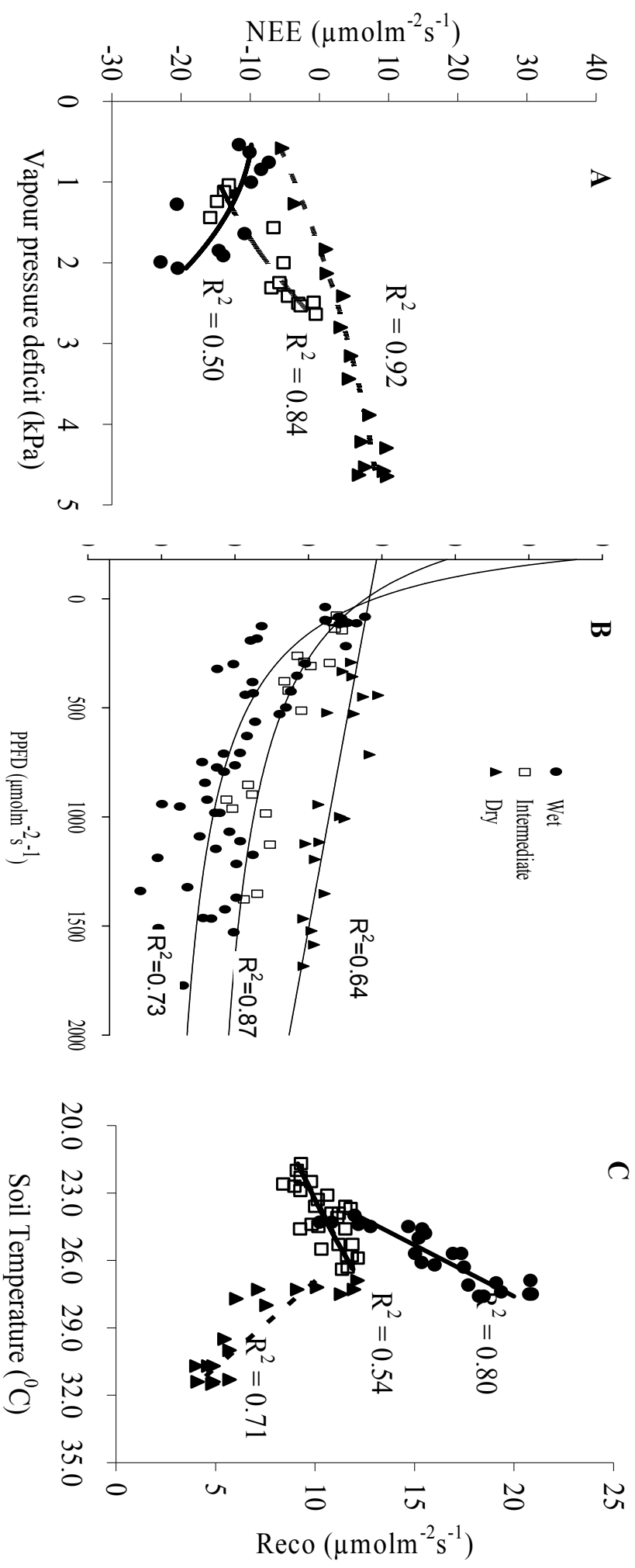

Figure 5: Correlation between net ecosystem CO2 exchange (NEE), and vapour pressure deficit (a), and photosynthetic photon flux density (PPFD) (b): and between ecosystem respiration (Reco) and soil temperature (c) for dry, intermediate and wet, soil water status. Values are means $( \pm S E)$ 
The rectangular hyperbolic light response curve (Eqn.3, Gilmanov et al., 2007) best described the correlation between PPFD and NEE under all the three SWC conditions, with $\mathrm{R}^{2}=0.64,0.87$, and 0.73 for dry, intermediate and wet conditions respectively (Fig. 5b). Fitted parameters from the regression between NEE and PFD showed that light utilization efficiency $(\alpha)$ and maximum $\mathrm{CO}_{2}$ assimilation rate of the canopy $(\beta)$ decreased with decreasing soil moisture (Table 1). Light utilization efficiency $(\alpha)$ was $0.08 \pm 0.04,-0.04 \pm 0.02$ and $-0.01 \pm 0.01$ while maximum $\mathrm{CO}_{2}$ assimilation rate of the canopy $(\beta)$ was $-30.39,23.93$ and 18.88 for the wet, intermediate and dry periods respectively.

Ecosystem respiration was linearly correlated to soil temperature with $\mathrm{R}^{2}=0.71$, $0.54 \& 0.80$ for dry, intermediate and wet soil conditions respectively (Fig. 5c). It increased with increasing soil temperature under wet and intermediate soil water conditions but decreased with increasing soil temperature under dry soil conditions.

Table 1. Best-fit parameters of the empirical hyperbolic light-response model (Eqn

3) derived from NEE data grouped according to the different phases of soil moisture and their statistics.

\begin{tabular}{|c|c|c|c|c|c|c|c|c|c|c|c|c|c|}
\hline \multirow{2}{*}{\begin{tabular}{l}
\multicolumn{1}{c}{ Soil } \\
moisture \\
condition
\end{tabular}} & \multirow[t]{2}{*}{$\alpha$} & \multirow[t]{2}{*}{$\beta$} & & \multirow[t]{2}{*}{$\gamma 0$} & \multicolumn{3}{|c|}{ SE } & \multirow[t]{2}{*}{ SE } & \multirow{2}{*}{\multicolumn{2}{|c|}{${ }_{y 0}$ SE }} & \multirow{2}{*}{\multicolumn{2}{|c|}{$\mathbf{R}^{2}$}} & \multirow[t]{2}{*}{$\mathbf{P}$} \\
\hline & & & & & $\alpha$ & & $\beta$ & & & & & & \\
\hline \multirow[t]{2}{*}{ wet } & - & - & & 9.0 & & 0.0 & & 2.6 & & 3.3 & & 0.7 & $<0$. \\
\hline & 0.08 & 30.39 & 2 & & 4 & & 0 & & 7 & & 3 & & 0001 \\
\hline \multirow{2}{*}{ 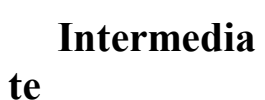 } & - & - & & 7.7 & & 0.0 & & 3.3 & & 2.2 & & 0.8 & $<\mathbf{0}$. \\
\hline & 0.04 & 23.93 & 8 & & 2 & & 9 & & 5 & & 7 & & 0001 \\
\hline \multirow[t]{2}{*}{ Dry } & - & - & & 8.2 & & 0.0 & & 3.1 & & 2.2 & & 0.6 & 0.0 \\
\hline & 0.01 & 18.87 & 8 & & 1 & & 4 & & 7 & & 4 & & 003 \\
\hline
\end{tabular}

\section{Discussion}

\section{Soil and plant nitrogen}

Soil moisture levels as measured by SWC followed the rainfall pattern and were highest in the wet and lowest in the dry periods. The seasonal variation of rainfall and hence SWC determined soil $\mathrm{C}$ and $\mathrm{N}$ levels. The increments in total soil $\mathrm{N}$ at the onset of the rains most likely resulted from enhanced mineralization of easily decomposable organic matter that had been accumulated during the dry season (Wedin, 1996; Kutsch et al., 2008). This is consistent with the rapid decline in the dead biomass at beginning of the rains in April. In addition, there was a strong positive correlation $\left(\mathrm{R}^{2}=0.80 ; \mathrm{P}<\right.$ 0.001 ) between soil $\mathrm{C}$ and $\mathrm{N}$ in this ecosystem.

The positive correlation of soil $\mathrm{C}$ and $\mathrm{N}$ is typical of the biological mineralization pattern of ecosystems in which soil nutrient levels are largely dependent on the soil litter content (Wedin, 1996; Ries \& Shugart, 2008). The synchrony in soil C and N levels to soil moisture regimes underscores the significant role that soil moisture plays in nutrient cycling in this savannah. Our observations are in agreement with the conclusion by Wang et al. (2009) that soil water availability largely determines the patterns and rates of nutrient cycling in African savannah.

Shoot and root $\mathrm{N}$ levels increased from the onset of rains implying a strong interrelation between nutrient release from soil and uptake by grass plants in this 
ecosystem. Similarly enhanced uptake of $\mathrm{N}$ following onset of rains had been noted among perennial grasses (Joffre, 1990; Wedin, 1996). The shoot and root N levels were tightly inter-linked in this ecosystem. Shoot $\mathrm{N}$ was high and root $\mathrm{N}$ low during the periods of peak active growth and biomass accumulation (May) but shoot $\mathrm{N}$ declined as root $\mathrm{N}$ increased by $50 \%$ at the end of the growing season pointing to possible relocation and accumulation of $\mathrm{N}$ in the roots (Baruch \& Gómez, 1996; Wedin, 1996). Furthermore the plant roots had higher $\mathrm{N}$ levels than the shoots during drought and shoot $\mathrm{C}: \mathrm{N}$ ratio was high during drought but low during wet periods with active growth implying transportation of $\mathrm{N}$ out of the shoots possibly to the roots. Enhanced root accumulated $\mathrm{N}$ would enable rapid regrowth of the grasses the next time environmental conditions become favourable. The synchronised $\mathrm{N}$ release and uptake and its probable relocation from the shoot and accumulation in the roots are strategies that restrict $\mathrm{N}$ losses from the ecosystem (Wedin, 1996). Such strategies are highly beneficial in Nlimited ecosystems like savannah.

\section{Ecosystem productivity and carbon fluxes}

Aboveground biomass development pattern followed the seasonal changes in soil moisture availability, with peak biomass coinciding with the end of the growing season. Similar biomass development trends had previously been noted in tropical savannah (Bourlićre \& Hadley, 1970; Scholes \& Walker, 1993).

Net ecosystem $\mathrm{CO}_{2}$ exchange, GPP, light use efficiency $(\alpha)$ and maximum canopy $\mathrm{CO}_{2}$ assimilation rate $(\beta)$ increased simultaneously with soil moisture peaking in the wet months. This is typical of most grassland, where gross and net photosynthesis are strongly correlated to green biomass (leaf area index) (Xu \& Baldocchi, 2004; Li et al., 2005; Otieno et al., 2009; Beringer et al., 2011). Given that shoot $\mathrm{N}$ also peaked in the wet season, the combined increase in green biomass (photosynthetic surface area), shoot $\mathrm{N}$ and light utilization efficiency facilitated rapid $\mathrm{CO}_{2}$ uptake resulting into the high GPP and NEE.

At a daily scale, GPP, NEE and PPFD increased in tandem, their maximum values coincided at midday, and NEE was strongly correlated to PPFD $\left(\mathrm{R}^{2}=0.73, \mathrm{P}<0.001\right)$ during wet periods. Gross primary production and NEE were most likely being driven by photosynthetic photon flux density when water was not limiting (Dai et al., 2004; Hastings et al., 2005) as has previously been reported in savannah (Ardő et al., 2008; Kutsch et al., 2008; Risch \& Frank 2010). During drought, the daily trends of GPP and NEE were reversed and they both decreased as VPD and PPFD increased. The decline in GPP and NEE during drought is attributed to either stomatal regulation by VPD (Eamus et al., 2001; Maherali et al., 2003; Li et al., 2005) or their direct limitation by soil moisture (Kanniah et al., 2010). Under drought with relatively high VPD, increasing VPD decreases stomatal conductance and hence GPP and NEE (Maherali et al., 2003; Li et al., 2005) in order to restrict plant water loss. Stomatal sensitivity to VPD is also known to increase with dropping leaf water potential in response to low soil moisture (Jones, 1998; Li et al., 2005). Kanniah et al. (2010) however, reported canopy light use efficiency to be more strongly correlated to SWC at $10 \mathrm{~cm}$ depth than the atmospheric VPD. It therefore implies that both low SWC and high VPD may work in synergy to lower the gross and net photosynthesis under dry soil conditions.

There was no evidence of direct GPP and NEE responses to ambient temperature. Instead, mean daily temperatures were lowest during the rainy seasons, when GPP and 
NEE were highest, and highest during drought when GPP and NEE were lowest. It is however, noteworthy that air temperature did not vary much over the year at our site.

Since soil N concentration did not differ over the year, we conclude that the seasonal differences in NEE and GPP must have resulted from the seasonality of soil moisture that caused the differences in green biomass (photosynthetic surface area), shoot $\mathrm{N}$, light utilization efficiency and maximum canopy $\mathrm{CO}_{2}$ assimilation rate. Similar driving role of soil moisture on gross and net photosynthesis of savannah had previously been reported (Xu \& Baldocchi, 2004; Merbold et al., 2008; Otieno et al., 2010).

Seasonally we observed no influence of soil temperature on ecosystem respiration instead, increasing temperatures were associated with drying soils and reduced $\mathrm{R}_{\text {eco }}$ over the year. This contradicted other studies (Lloyd \& Taylor 1994; Xu et al., 2005; Flanagan \& Johnson, 2005; Li et al., 2008) but was consistent to previous work of Otieno et al. (2010) that reported minimal soil temperature control over $\mathrm{R}_{\text {eco }}$ at the same study site. It is attributed to soil moisture controlling $\mathrm{R}_{\text {eco }}$ directly through its effects on soil microbial activity (Bowden et al., 1993, Hanson et al., 2000) and indirectly through assimilation and transport of assimilates to the respiring surfaces and into the soil (Kuzyakov \& Cheng, 2004). The indirect influence of soil moisture on $R_{\text {eco }}$ via $C$ assimilation is supported by our strong positive correlation between $R_{\text {eco }}$ and GPP $\left(R^{2}=\right.$ $0.68, \mathrm{P} \leq 0.001)$.

Contrary to our seasonal data and work of Otieno et al. (2010) at the same site, the daily trends revealed controlling effects of soil temperature on $R_{\text {eco. Ecosystem }}$ respiration increased with increasing soil temperature under wet and intermediate soil water conditions but decreased with increasing soil temperature during drought and was strongly correlated to soil temperature $\left(\mathrm{R}^{2}=0.71\right.$ and $\mathrm{R}^{2}=0.80$ for dry and wet periods respectively). The trend under wet soil conditions is in agreement to the observation that when water is not limiting, $\mathrm{R}_{\text {eco }}$ is largely governed by the soil temperature (Joffre et al., 2003; Flanagan \& Johnson, 2005; Li et al., 2008).

The decoupling of $\mathrm{R}_{\text {eco }}$ to soil temperature as noted during drought is not new having previously been reported (Flanagan \& Johnson, 2005; Tang \& Baldocchi, 2005) and is attributed to decline in the sensitivity of respiration to temperature with increasing soil temperature and decreasing soil moisture (Xu \& Baldocchi, 2004; Flanagan \& Johnson, 2005). We speculate that the mismatch between $R_{\text {eco }}$ and soil temperature during drought may have resulted from, (i) restrained autotrophic respiration due to low carbon source for respiration as photosynthetic rates declined in response to high temperature, extremely high VPD, and low soil moisture; and (ii) decreased sensitivity of water stressed microbial decomposers (a major contributor to soil respiration) to high temperatures (Lloyd \& Taylor, 1994; Tang \& Baldocchi, (2005).

We attribute the anomaly in the seasonal and daily $\mathrm{R}_{\text {eco }}$ correlations with soil temperature to the greater daily $\left(5\right.$ to $\left.7^{0} \mathrm{C}\right)$ compared to annual temperature fluctuations $\left(2\right.$ to $\left.3^{0} \mathrm{C}\right)$ at our study site. The daily fluctuations in temperature were evened out over time (seasonally) leaving the seasonally significantly different soil moisture to determine the ecosystem respiration. Such overriding role of soil moisture on ecosystem respiration relative to temperature is not new having been reported by others $(\mathrm{Xu} \&$ Baldocchi, 2004; Tang \& Baldocchi, 2005; Otieno et al., 2010).

Highest mean carbon fluxes were $3.21 \pm 0.99,8.21 \pm 1.02$ and $4.67 \pm 1.06 \mu \mathrm{molm}^{-2} \mathrm{~s}^{-1}$ during drought and $-13.86 \pm 1.48,15.03 \pm 0.98$, and $27.73 \pm 1.47 \mu \mathrm{molm}^{-2} \mathrm{~s}^{-1}$ during wet periods for NEE, $\mathrm{R}_{\mathrm{eco}}$ and GPP respectively. The ecosystem was a net $\mathrm{C}$ sink over most of the year except at the beginning when SWC fell below $25 \%$ and NEE was positive. 
This is contrary to the reports from semi arid savannah of Sudan (Ardö et al., 2008) which indicated a sink albeit a weak one even during the dry spell. The difference could stem from the fact that unlike Ardo et al. (2008) who integrated NEE from both the trees and herbaceous layer, we only measured the latterr. The herbaceous layer ceases growth and senesces (Eamus et al., 2001; Baldocchi et al., 2004) during drought, while the deep rooted trees would still continue accessing soil moisture and hence photosynthesising.

\section{Conclusion}

Seasonally, the ecosystem $\mathrm{C}$ fluxes and biomass production of this moist savannah were largely determined by rainfall and hence available soil moisture. Soil N, and shoot $\mathrm{N}$ levels, NEE, $\mathrm{R}_{\mathrm{eco}}$, and biomass development followed a seasonal pattern governed by the seasonality of rainfall. $\mathrm{N}$ mobility among its pools of soil, plant roots and shoots were tightly coupled in a manner that served to restrict its loss from the ecosystem and to enhance its availability and utilization by plants.

The daily ecosystem $\mathrm{C}$ fluxes and their relationship to the daily weather parameters were also determined by soil moisture levels as dictated by rainfall. However, on a daily scale, Gross primary production and net ecosystem $\mathrm{CO}_{2}$ exchange were regulated by photosynthetic photon flux density when water was readily available and vapour pressure deficit during drought. Ecosystem respiration was controlled by soil temperature. We recommend intense measurements during periods of greatest temperature variations at the site (July-January) to rule out seasonal influence of temperature on ecosystem respiration.

Acknowledgements. We acknowledge the Kenya National Youth Service (NYS), Lambwe station for hosting the research and Prof. J. Tenhunen for his support during our field activities and with ideas during the project design. We are grateful to MS. Margarete Wartinger for her support with the soil and plant sample analyses. This work was supported by funds from the British Ecological Society (BES) under grant number 1430/1802.

\section{REFERENCES}

[1] Adams, M.E. (1996): Savannah environments. -In: Adams, W., Goudie A. \& Orme A. (eds.) the physical geography of Africa, Oxford University Press, Oxford, UK.

[2] Ardö, J., Mölder, M., El-Tahir, A.B. \& Elkhidir, H.A. (2008): Seasonal variation of carbon fluxes in a sparse savanna in semi arid Sudan. - Carbon Balance and Management 3:7 doi:10.1186/1750-0680-3-7.

[3] Baldocchi D. D., Xu L., \& Kiang N. (2004): How plant functional-type, weather, seasonal drought, and soil physical properties alter water and energy fluxes of an oak-grass savanna and an annual grassland. - Agricultural and Forest Meteorology 123: 13-39.

[4] Baruch Z. \& Gómez J.A. (1996): Dynamics of energy and nutrient concentration and construction cost in a native and two alien $\mathrm{C} 4$ grasses from two neotropical savannas. Plant and Soil 181 175-184.

[5] Beringer J., J. Hacker, L.B. Hutley, R. Leuning, S.K. Arndt, R. Amiri, L. Bannehr, L. Cernusak, S. Grover, C. Hensley, D. Hocking, P. Isaac, H. Jamali, K, Kanniah, S. Livesley, B. Neininger, K.T. Paw, W, Sea, D. Sraten, N. Tapper, R. Weinmann, S. Wood \& Zegelin, S. (2011): SPECIAL. - Savanna Patterns of Energy and Carbon Integrated 
Across the Landscape. American Meteorological Society., doi: 10.1175/2011BAMS2948.1.

[6] Bombelli, A. M. Henry, S. Castaldi, S. Adu-Bredu, A. Arneth, A. de Grandcourt, E. Grieco, W. L. Kutsch, V. Lehsten A. Rasile. M. Reichstein, K. Tansey, U. Weber, \& Valentini, R. (2009): The Sub-Saharan Africa carbon balance, an overview. Biogeosciences Discuss. 6: 2085-2123.

[7] Bourlićre F. \& Hadley, M. (1970): The Ecology of Tropical Savannas. - Annual Review of Ecology and Systematics 1: 125-152.

[8] Bowden, R. D., Castro, M. S., Melillo, J. M., Steudler, P. A. \& Aber J. D. (1993): Fluxes of greenhouse gases between soils and the atmosphere in a temperate forest following a simulated hurricane blowdown. - Biogeochemistry 21:61-71.

[9] Ciais, P., S.-L. Piao, P. Cadule, P. Friedlingstein, \& Ch'edin, A. (2009): Variability and recent trends in the African terrestrial carbon balance. - Biogeosciences 6: 1935-1948.

[10] Dai, Y., Dickson, R.E. \& Wang, Y.P. (2004): A two-big-leaf model for canopy temperature, photosynthesis, and stomatal conductance. - American Meteorological Society 17: 2281-2299.

[11] Droesler, M. (2005): Trace gas exchange and climatic relevance of bog ecosystems, Southern Germany. PhD thesis. - Technical University of Munich, Germany.

[12] Eamus, D., Hutley, L.B. \& O'Grady, A.P. (2001): Daily and seasonal patterns of carbon and water fluxes above a north Australian savanna. - Tree Physiology 21: 977-988.

[13] Flanagan L. B. \& Johnson, B.G. (2005): Interacting effects of temperature, soil moisture and plant biomass production on ecosystem respiration in a northern temperate grassland. - Agricultural and Forest Meteorology 130: 237-253.

[14] Gilmanov, T.G., Soussana, J.F., Aires, L., Allard, V., Amman, C., Balzarolo, M., Barcza, Z., Bernhofer, C., Campbell, C.L., Cernusca, A., Cescatti, A., Clifton-Brown, J., Dirks, B.O.M., Dore, S., Eugster, W., Fuhrer, J., Gimeno, C., Gruenwald, T., Hazspra, L., Hensen, A., Ibrom, A., Jacobs, A.F.G., Jones, M.B., Lanigan, G., Laurila, T., Lohila, A., Manca, G., Marcolla, B., Nagy, Z., Pilgaard, K., Pinter, K., Pio, C., Raschi, A., Rogiers, N., Sanz, M.J., Stefani, P., Sutton, M., Tuba, Z., Valentini, R., Williams, M.L. \& Wohlfart, G. (2007): Partitioning European grassland net ecosystem CO2 exchange into grass primary productivity and ecosystem respiration using light response function analysis. - Agriculture Ecosystems and Environment 121:93-120.

[15] Grace, J., San Jose, J., Meir, P., Miranda, H.S. \& Montes, R.A. (2006): Productivity and carbon fluxes of tropical savannas. - Journal of Biogeography 33: 387-400.

[16] Hall D.O., Scurlock J.M.O., Bolhar-Nordenkampf H.R., Leegood R.C., Long S.P. (1992): Photosynthesis and Production in a Changing Environment: A field and laboratory manual., $464 \mathrm{pp}$.

[17] Hanson, P.J., Edwards, N.T., Garten, C.T. \& Andrews, J.A. (2000): Separating root and soil microbial contributions to soil respiration: a review of methods and observations. Biogeochemistry 48:115-146.

[18] Hastings S.J., Oechel, W.C. \& Muhlia-Melo, A. (2005): Diurnal, seasonal and annual variation in the net ecosystem $\mathrm{CO} 2$ exchange of a desert shrub community (Sarcocaulescent) in Baja California, Mexico. - Global Change Biology 11: 927-939., doi: 10.1111/j.1365-2486.2005.00951.x.

[19] IPCC, 2007. Climate Change (2007): The physical science basis: summary for policy makers. IPCC WGI Fourth Assessment Report.

[20] Joffre R., (1990): Plant and soil nitrogen dynamics in Mediterranean grasslands: a comparison of annual and perennial grasses. - Oecologia 85:142-149.

[21] Joffre, R., Ourcivala, J.M., Rambala, S. \& Rocheteaua, A. (2003): The key-role of topsoil moisture on $\mathrm{CO} 2$ efflux from a Mediterranean Quercus ilex forest. - Ann. For. Sci 60: $519-526$.

[22] Jones H.G. (1998): Stomatal control of photosynthesis and transpiration. - Journal of Experimental Botany 49: 387-398. 
[23] Kanniah, K.D., Beringer, J. \& Hutley, L. (2010): Comparative role of key environmental factors in determining savannah productivity and carbon fluxes. A review with special reference to northern Australia. - Progress in Physical Geography 34 (4): 459-490.

[24] Kutsch, W.L., Hanan, N., Scholes, R.J., Mchugh, I., Kubheka, W., Eckhardt, H. \& Williams, C. (2008): Response of carbon fluxes to water relations in a savanna ecosystem in South Africa. - Biogeosciences 5: 4035-4069.

[25] Kuzyakov, Y. \& Cheng, W. (2004): Photosynthesis controls of CO2 efflux from maize rhizosphere. - Plant and Soil 263:85-99.

[26] Li, S.G., Asanuma, J., Eugster, W., Kotani, A., Liu, J.J., Urano, T., Oikawa, T., Davaa, G., Oyunbaatar D. \& Sugita, M. (2005): Net ecosystem carbon dioxide exchange over grazed steppe in central Mongolia. - Global Change Biology 11: 1941-1955.

[27] Li, Y.L., Otieno, D., Owen, K., Zhang, Y., Tenhunen, J., Rao, X.Q. \& Lin Y.B. (2008): Temporal variability in soil $\mathrm{CO} 2$ emission in an orchard forest ecosystem. - Pedosphere 18: 273-283.

[28] Lloyd, J. \& Taylor, J.A. (1994): On the temperature dependence of soil respiration. Functional Ecology 8:315-323.

[29] Maherali H., Johnson, H.B., \& Jackson, R.B. (2003): Stomatal sensitivity to vapour pressure difference over a subambient to elevated $\mathrm{CO} 2$ gradient in a $\mathrm{C} 3 / \mathrm{C} 4$ grassland. Plant, Cell and Environment 26: 1297-1306.

[30] Markert, B., (1996): Instrumental Element and Multi-element Analysis of Plant Samples - Methods and Applications. - John Wiley \& Sons Ltd., New York, US.

[31] Merbold. L., Ardö. J., Arneth. A., Scholes, R.J., Nouvellon, Y., De Grandcourt, A., Archibald, S., Bonnefond, J.M., Boulain, N., Bruemmer, C., Brueggemann, N., Cappelaere, B., Ceschia, E., El-Khidir, H.A.M., El-Tahir, B.A., Falk, U., Lloyd, J., Kergoat, L., Le Dantec, V., Mougin, E., Muchinda, M., Mukelabai, M.M., Ramier, D., Roupsard, O., Timouk, F., Veenendaal, E.M. \& Kutsch, W.L. (2008): Precipitation as driver of carbon fluxes in 11 African ecosystems. - Biogeosciences 5: 4071-4105.

[32] Otieno D.O., K'Otuto, G.O., Ja 'kli, B., Schro"ttle, P., Maina, J.N., Jung, E. \& Onyango, J.C. (2011): Spatial heterogeneity in ecosystem structure and productivity in a moist Kenyan savanna. - Journal of Plant Ecology 212:769-783.

[33] Otieno, D.O., K'Otuto, G.O., Maina, J.N., Kuzyakov, Y. \& Onyango, J.C. (2010): Responses of ecosystem carbon dioxide fluxes to soil moisture fluctuations in a moist Kenyan savannah. - Journal of Tropical Ecology 26: 1-14.

[34] Otieno D. O., Wartinger, M., Nishiwaki, A., Hussain, M.Z., Muhr, J., Borken W. \& Lishaid G. (2009): Responses of CO2 exchange and primary production of the ecosystem components to environmental changes in a mountain peatland. - Ecosystems 12:590-603.

[35] Reis, L.P. \& Shugart, H.H. (2008): Nutrient limitations on understory grass productivity and carbon assimilation in an African woodland savanna. - Journal of Arid Environments 72:1423-1430.

[36] Risch, A.C. \& Frank, D.A. (2010): Diurnal and seasonal patterns in ecosystem CO2 fluxes and their controls in a Temperate Grassland. - Rangeland Ecology Management 63:62-71., doi: 10.2111/08-066.1.

[37] Rodriguez-Iturbe, I., D’odorico, P., Porporato, A. \& Ridolfi, L. (1999): Tree-grass coexistence in savannas: the role of spatial dynamics and climate fluctuations. Geophysical Research Letters 26:247-250.

[38] Scholes R.J. (1990): The influence of soil fertility on the ecology of African savannahs. Journal of Biogeography 17: 417-419.

[39] Scholes R.J. \& Archer, S.R. (1997): Tree-grass interactions in savannas. - Annual Review of Ecology \& Sytematics 28: 517-544.

[40] Scholes, R.J. \& Walker, B.H. (1993): An African savanna: synthesis of the Nylsvley Study. - Cambridge University Press, Cambridge UK.

[41] Steeneveld, G.J. (2002): On photosynthesis parameters for the A-gs surface scheme for high vegetation. Meteorology and air quality group of Wageningen University. 
[42] Tang, J. \& Baldocchi, D.D. (2005): Spatial-temporal variation in soil respiration in an oak-grass savanna ecosystem in California and its partitioning into autotrophic and heterotrophic components. - Biogeochemistry 73: 183-207.

[43] Wang, L., Okin, G.S., Gaylor, K.K., \& Macko, S.A. (2009): Spatial heterogeneity and sources of soil C in Southern African savannah. - Geoderma 149: 402-408.

[44] Wedin, D.A. (1996): Nutrient cycling in grasslands: An ecologist's perspective. - In: Joost, R.E. \& Roberts, C.A. (eds.) Nutrient cycling in forages, Potash and Phosphate Institute, Manhattan.

[45] Williams, C.A., Hanan, N.P., Neff, J.C., Scholes, R.J., Berry, J.A., Denning, A.S. \& Baker D.F. (2007): Africa and the global carbon cycle. - Carbon Balance Management 2: 3., doi:10.1186/1750-0680-2-3.

[46] Wohlfahrt G, Anfang Ch, Bahn M, Haslwanter A, Newesely Ch, Schmitt M, Droeler M, Pfadenhauer J, Cernusca A (2005): Quantifying ecosystem respiration of a medow using eddy covariance, chambers and modelling. - Agric For Meteorol 128: 141-162.

[47] Xu, L. \& Baldocchi, D.D. (2004): Seasonal variation in carbon dioxide exchange over Mediterranean annual grassland in California. - Agricultural and Forest Meteorology 1232: 79-96.

[48] Xu, L., Baldocchi, D. D. \& Tang, J. (2005): How soil moisture, rain pulses and growth alter the response of ecosystem respiration to temperature. - Global Biogeochemical Cycles 18: GB4002., doi:10.1029/2004GB002281. 